УДК 792.028:654.195](045)

ORCID ID: 0000-0001-6404-5775

Недін Лариса Миколаӥвна, заслужена артистка України, доцент кафедри акторської майстерності та режисури драми, доцент кафедри сценічної мови. Київський національний університет театру, кіно i телебачення імені І. К. Карпенка-Карого, Київ

Недин Лариса Николаевна, заслуженная артистка Украины, доцент кафедры актёрского мастерства и режиссуры драмы, доцент кафедры сценической речи. Киевский национальный университет театра, кино и телевидения имени И. К. Карпенко-Карого, Киев

Nedin Larysa, Honoured Artist of Ukraine, Associate Professor of Actor Mastery and Dramas directing Department, Associate Professor of the Stage Speech Department. Kyiv National I. K. Karpenko-Karyi Theatre, Cinema and Television University, Kyiv

\title{
ОСОБЛИВОСТІ ВНУТРІШНЬОЇ І ЗОВНІШНЬОЇ АКТОРСЬКОЇ ТЕХНІКИ В ГУМОРИСТИЧНИХ ПЕРЕДАЧАХ ПОСТАНОВОЧНО- ІГРОВОГО ХАРАКТЕРУ. РАДІОМИСТЕЦТВО
}

\begin{abstract}
Анотація. У статті розглянуто спектр внутрішньої і зовнішньої акторської техніки в суміжній сфері діяльності драматичного актора - радіомистецтві, який з наукової точки зору раніше не досліджувався. Увага зосереджена на розважальних передачах постановочно-ігрового характеру, участь в яких значно розширює професійний діапазон і творчу палітру актора. Акцент зроблено на особливостях внутрішньої і зовнішньої техніки — як засобах виразності в радіопередачах гумористичного жанру.

Ключові слова: внутрішня техніка, зовнішня техніка, радіо, актор, режисер, ритм, перевтілення, «Від суботи до суботи», «А ми до вас в ранковий час».

Постановка проблеми та ї̈ актуальність. Коли говоримо про фахове, професійне виховання актора, слід акцентувати, що жоден майстер-педагог, як і театральна школа загалом, не можуть надати конкретного рецепту творчості, щоб навчити грати. Основа навчального процесу - створення необхідних умов шляхом усунення внутрішніх і зовнішніх перешкод, які, як правило, виникають на шляху початківця (студента) до органічної творчості. Навчитися творити (грати) лише завдяки технічним прийомам неможливо. Але можливо і треба створити сприятливі умови для розкриття потенціалу закладеного таланту.

Відомо, що єдиним інструментом актора $є$ його психофізика. Отже, цей «інструмент» має бути

здатним сприймати творчі імпульси, тобто народжувати, відтворювати логічні дії, а для цього треба професійно удосконалювати внутрішню (психічну) і зовнішню (фізичну) складові. Ось чому в акторській освіті $є$ надважливими поняття «внутрішня техніка» $\mathrm{i}$ «зовнішня техніка». Внутрішня техніка актора — це вміння створювати необхідні психічні умови для органічного народження дії. Зовнішня техніка - це техніка мовлення, постановка голосу, ритміка, пластика і т.д. - ряд навичок і вмінь, які є зовнішньою технікою. Поняття «зовнішня» $\mathrm{i}$ «внутрішня» техніка мають «взаємопроникати», взаємодіяти. Лише за таких умов актор володітиме надважливою складовою професії - чуттям і відчуттям сценічної правди і форми.
\end{abstract}


Мова театру універсальна, саме тому театр органічно «прижився» і в телевізійному просторі, і як складова радіомистецтва, не лише у вигляді трансляційних записів, а й таких жанрових форм, як телетеатр і радіотеатр. А це розширило професійне поле діяльності актора.

Mema cmammi - розкрити специфіку акторської техніки в суміжній сфері діяльності драматичного актора - радіомистецтві, акцентуючи увагу на особливостях внутрішньої і зовнішньої техніки як засобах виразності в радіопередачах гумористичного жанру.

Виклад основного матеріалу. Починаючи з 90-х років ХХ століття яскраво простежується тенденція відсоткового збільшення в теле- і радіоефірі розважальних передач, шоу. В наш час ï багато, як грибів після дощу. Можна сміливо стверджувати, що передвісниками в інформаційному просторі, зокрема радіо, були гумористичні передачі постановочно-ігрового характеру «Від суботи до суботи» та «А ми до вас в ранковий час». Автором ідеї та редактором цих передач був журналіст Григорій Мельник.

З 1968 року на хвилях першого каналу Українського радіо щосуботи звучала передача «Від суботи до суботи», яка дуже швидко набула популярності. Всі організаційно-творчі процеси (від редакторського задуму до виходу в ефір: сценарій, робота 3 позаштатними авторами-гумористами, сатириками, режисером-постановником, акторами, музичне оформлення, прем'єри, інтерв'ю) здійснював і контролював Г. Мельник. Тільки через дев'ять років 3 появою передачі «А ми до вас в ранковий час», яка звучала в ефірі спочатку щосуботи і щонеділі, а згодом щодня, долучилися журналісти-редактори Віктор Герасимов, Інна Цацко, Людмила Оніщенко. Режисери-постановники Володимир Бохонко та Юрій Дзюба запросили до співпраці акторів, серед яких Степан Олексенко, Анатолій Пазенко, Олег Комаров, Ірина Дука, Ада Роговцева, Зоя Віхарева, Анатолій Васильєв, Наталя Лотоцька, Інна Єрмоленко.

...Для створення «рейтингового обличчя» програми за справу взялися наші незабутні гумористи: Андрій Сова, Павло Глазовий, Тарапунька і Штепсель (Юрій Тимошенко, Юхим Березін). Позивні цих передач лунали в кожній сільській домівці, $з$ вікон міських квартир, запрошуючи слухачів у світ дотепного слова, музики, даруючи людям гарний настрій. Інтермедії, фейлетони, гуморески, усмішки, які звучали в передачах «Від суботи до суботи», «А ми до вас в ранковий час», одразу ставали популярними, їх переписували, передавали з вуст у вуста, виконували на концертних майданчиках ... (Недін, 2020, с. 121-129)

Як стверджував театральний режисер Е. М. Митницький, «... сьогодні про сьогодні дуже важко писати. Інакше це буде на злобу дня, це будуть куплети або анекдоти... I тому режисурі не уникнути певної майже месіанської заангажованості». (Митницький, 1998, с. 27) Так ось, те, що для театру було і $€$ небезпечними тенденціями, в жанрі розважальних передач було і залишається актуальним. Розважально- епатажний елемент завжди домінує.

Очоливши у 1995-му році редакцію розважальних Українського радіо, довелося авторці цієї статті Ларисі Недін успадкувати й обов'язки керівника передач «Від суботи до суботи», «А ми до вас в ранковий час», які виявились довгожительками ефіру. Вони не лише не втратили своєї актуальності, а й стали ще популярнішими, оскільки демократичні зміни в незалежній Україні вплинули на процеси, пов'язані зі свободою слова. Редакторські обов'язки на той час перебрали на себе Ігор Стратій та Олена Терентьєва, до режисерської групи приєднались Василь Обручов і Юрій Ємельяненко.

У 2001-2002 роках відбулась реорганізація структури Українського радіо. Впроваджувалися ринкові моделі в структуру мовлення. «Старе» радіо відходило в минуле, народжувалось радіо не лише як ефірна структура, а й як продюсерський центр. 3'явилась потреба у позаефірній діяльності - концерти, творчі зустрічі, конкурси, ювілейні мистецькі заходи, в яких брали участь ті ж актори, які записували передачі в студії. Унаочнилась, увиразнилась природа відмінностей акторського існування ( діяння) на сцені, тобто в звичних умовах, i в процесі запису в радіостудії передач постановочно-ігрового характеру.

У 2005 році режисерами-постановниками передач стали Зінаїда Журавльова (мала великий досвід роботи в цьому жанрі, оскільки довгий час була ведучою і співрежисером телевізійної програми «П'ять хвилин на роздуми»), Лариса Потапенко, В'ячеслав Глушенко, постійними ведучими - Лариса Недін, Олександр Сафонов, голосову палітру творили Тамара Стратієнко, Леонід Марченко, Людмила Ігнатенко, Василь Довжик, пізніше приєдналися Євгенія Гулякіна, Василь Чорношкур, В'ячеслав Махлай, Анатолій Гнатюк, Вадим Полікарпов, Софія Гордійчук, Дмитро Коростильов, Карина Сухорукова, Валерія Бондарук.

Специфіка передач, про які йдеться, полягає в тому, що редактор - автор сценарію - добирає 
короткі літературні дотепи, оповідки, усмішки, гуморески, анекдоти, зрідка невеличкі фейлетони, актори ж мають їх не просто озвучити, а й зіграти. В одному випуску передачі актор може зіграти 5-7 ролей. Оскільки радіо не дає можливості бачити, то головним засобом виразності залишається тільки голос, який передає згусток емоцій персонажа, його характер. Оскільки репетиційний період запису передач зведений до мінімуму, то вивчення дійсності, яка відображена в образах, аналіз матеріалу, закладеного драматургом, письменником, методологія роботи актора, яка передбачає в театрі тривалий репетиційний період, тут зводиться до проб перед мікрофоном. Момент творчого перевтілення, тобто народження образу, відбувається дуже швидко, почасти імпровізаційно, в стилі стенд-апу (реалії не лише сьогодення: записи кількох випусків передачі відбуваються за півтори-дві години, актори приходять до студії або до ранкових репетицій в театрі, або між репетицією і виставою). Тобто на радіо відсутній тривалий, напружений, усвідомлений репетиційний період роботи актора над роллю, який є основою творчого акту в театрі. На перший план виходить така складова професії, як гостра характерність, яка допомагає активно, миттєво розкривати дійову природу подій. Голосова, тембральна характерність - це особливий вид таланту. Актор лише голосом передає, скажімо, фізичне самопочуття, вік, фізичний стан, а слухач домальовує своєю уявою образ, перетворюючи все почуте в стрічку бачення в своїй свідомості.

Дивитися - заняття пасивне, бачити - активна життєва дія. В процесі запису передач, прочитавши літературний матеріал, актор, який грає перед мікрофоном, усвідомлено працює за схемою: бачити — означає поєднати зір і думку в одному фокусі, уявляючи те, про що йдеться, оскільки в радіостудії не вибудовують мізансцен, тут немає фізичної дії героїв, не звучить музика, яка створює атмосферу, немає екрана, де можна бачити, що і де відбувається і т.д. Все передається лише голосом.

У розважальних передачах особливу роль відіграє темпоритм. Насправді, дуже важко навчити актора розуміти, що таке внутрішня зміна. Вона визначається ритмом. Часто режисер робить зауваження: не той темпоритм, змініть темпоритм. Далеко не кожен це розуміс. Темп - це рух зовнішніх речей у процесі мізансценування, а ритм - це швидка внутрішня реакція. Скажімо, людина, яка чогось прагне, існує інакше, ніж байдужа. Проблема перевтілення є, почасти, пробле- мою ритмічної зміни. Оскільки на радіо відсутні зовнішні засоби виразності, то швидке перевтілення в героїв анекдотів, гуморесок, оповідок, усмішок відбувається завдяки зміні внутрішнього ритму. Декому це дане від природи (характерність). Ритм - це дієвість, коли актор розкриває в собі можливість змінитися. Актори з вузьким творчим діапазоном мають обмежені можливості. Радіомікрофон це відразу увиразнює. Такі актори не приживаються в творчих командах, які працюють у розважальному жанрі.

Актор має бути емоційним, тобто на сцені потрібно вміти мислити, але мислення сконцентроване, емоційно забарвлене. Ще більше воно необхідне у постановочних розважальних радіопередачах, бо гумористичний, сатиричний жанр передбачає глибокі підтексти, паралелі, відверті натяки, провокативність. Засобами виразності стають голосові контрасти, відтінки, напівтони чи яскрава характерність.

Загальновідома істина: актор повинен володіти голосом і тілом. Коли додати внутрішню наповненість - перед нами непересічна акторська індивідуальність. Та будьмо відверті, десь після тридцяти років більшість драматичних акторів не самовдосконалюються, не працюють над собою. Недарма побутує думка, що з- поміж виконавців, саме актори найлінивіші. Приміром, оперний співак хоч і не часто виходить на сцену, та щодня тренується - співає гами, вокалізи, повторює свої арії. Музикант теж щодня вправляється на своєму інструменті. Соліст балету щодня працює в балетному залі біля станка. Драматичні актори далеко не завжди «розігрівають» свій мовний апарат перед виставою. Опанувавши ази техніки в студентські роки, дозволяють собі не тренуватися або ж замало працювати над собою. У будь-якій сфері діяльності небажання самовдосконалюватись - ознака непрофесіоналізму. Всі актори, без винятку, хто в різні роки працював над створенням передач «Від суботи до суботи», «А ми до вас в ранковий час», стверджували, що саме постійні радіозаписи змушували відпрацьовувати мовно-голосові комплекси вправ, що допомагало підтримувати професійну форму, а це, безумовно, позитивно позначалось і на роботі в театрі.

Існує ще одна професійна проблема - акторські штампи. Не повторюватися надзвичайно складно навіть дуже обдарованим акторам, майстрам. Та й вдалі знахідки з часом стають штампами, бо вони вже перевірені на публіці й актор свідомо їх застосовує. В аудіомистецтві досить часто штамп тотожний амплуа. Скажімо, раніше ролі 
дітей озвучували не діти, а професійні актори, частіше, які працювали в Театрі юного глядача. I роками актрису чи актора запрошували на записи саме тому, що вони вміли це робити феноменально. Або ж такий приклад: не кожен актор вміє органічно зіграти п'яну людину, щоб при цьому мова була розбірливою (для радіо це надважливо). Знову ж, режисер запрошує актора, у якого це завжди добре виходить. І хоч це штамп, але доречний і необхідний в тій чи іншій передачі. Це той випадок, коли знайдено спільну мову режисера й актора i не доводиться витрачати дорогоцінний студійний час, щоб когось вчити чи показувати, як треба, записуючи багато дублів.

Процес творчості має відбуватися в умовах взаємної симпатії, тому всі режисери-постановники передач, про які йдеться в статті, завжди добирали «своїх» акторів, творили «свою» команду. Створення атмосфери товариських взаємин - найважливіша передумова творчості. Такі взаємини обов'язкові й зумовлюють етику і професіоналізм не лише в театрі, а й у процесі роботи на радіо. Чому актори мали за честь записуватись у радіопередачах? Адже не йшлося про головні, масштабні ролі. В гумористичних передачах всі ролі невеличкі, за театральними мірками - епізодичні. Але ці передачі популярні, акторів упізнають за голосом. А для того щоб 45-хвилинна передача звучала як на одному подиху, щоб залишала в свідомості слухача позитивні емоції, приємні враження, вона має бути бездоганною як мистецький, творчий продукт. Це досягається ансамблевою роботою: редактор - сценарист - peжисер - актор, музичний редактор. Найважливіша роль у цьому ланцюжку відводиться акторові, який втілює задум сценариста і режисера. Наведу лише декілька прикладів. Багато років ведучою передачі «Від суботи до суботи» була народна артистка України Наталя Лотоцька. Вона навіть ображалась, що, маючи чималий послужний список зіграних ролей у театрі, популярною стала завдяки передачі. Хоч куди б приїздив 3 гастролями театр ім. І.Франка, ії зустрічали словами: «То це ви ведуча програми «Від суботи до суботи!». Те саме було і в творчій долі акторів театру ім. Лесі Українки - народних артистів України Анатолія Пазенка, Олега Комарова.

Завдяки точним завданням режисера, актор перед мікрофоном вибудовує зі слухацькою аудиторією (яку не бачить) безбар'єрний зв'язок, своєрідний дует. Це неабиякий хист. Симбіоз внутрішньої та зовнішньої акторської техніки створює емоційне поле у свідомості самого актора й має передаватися слухачеві. Пошук виражальних засобів зводиться до віртуозного володіння голосом. Текст передачі - це не лише привід для ефірного (радіо) існування актора, а зміст життя героїв інтермедій, коло думок, напрямок мислення, безперервність пошуку думки «між рядками» майстром, в тексті - дещиця. В гумористичному, сатиричному жанрах важливіше те, про що не написано, але заради чого писалось. Для цього потрібна переконливість, особиста мета, зрештою, актор-особистість, у якому гармонійно поєднуються професіоналізм і суто людське наповнення. Не завжди актор, який $є$ цікавою, яскравою (харизматичною) особистістю в житті (дотепник, майстер розповідати анекдоти), органічний у розважальних передачах. Випробування (кастинги) проходять ті, хто володіє умінням думати перед мікрофоном, бачити події, чути партнерів, має досконало розвинену внутрішню техніку, а найголовніше - вміють проєктувати на свій внутрішній екран. Фантазія такого актора народжує нескінченні картинки. Такий актор обов'язково живе в ритмах часу, відчуває ці ритми, реагує на всі події, що з ним відбуваються, пам'ятає що ці події відкрили нового. Працюючи в розважальних передачах, треба вміти розпізнавати природу почуттів, властиву письменникові-гумористу, сатирику, зрештою, часу, характеру. Це дуже важлива здатність. Навчити цьому вкрай складно. Це радше зі сфери понять «обдарованість», «талант».

Професіоналізм актора — це не лише сума технічних прийомів. Психотехніка потрібна, але «демонструвати» слухачеві іiі не слід. Вона має проявлятись в особистому осягненні життєвих подій і відгуку-вібраціії. Психотехніка — це головний інструмент дієвого аналізу. Зовнішня техніка не має зводитись до демонстрації, скажімо, поставленого голосу (хоч радіо провокує до подібного). Красивий голос - це чудово, але сам по собі він не має цінності, як і красива зовнішність. Голос має бути інструментом, який допомагає створювати характери. В акторові найцінніше це громадянська позиція, усвідомлення і розуміння політичних і моральних процесів у суспільстві. Коли артисти, задіяні в передачах, концертували, приїздили на творчі зустрічі, глядачам найбільше запам'ятовувалися виступи народних артистів України Анатолія Литвинова та Анатолія Демчука, бо в їхньому репертуарі переважали твори на політичні теми. Глядачі чітко вгадували, про кого i про що йдеться, хоча жодного разу не звучали конкретні прізвища. Артистів часто просили виконувати інтермедії на «біс». 
Дуже часто плутають поняття «акторська особистість» i «типажність». Коли драматург пише п’єсу, він розраховує на конкретну індивідуальність, яка, використовуючи свій внутрішній потенціал, може донести думку автора і без великих монологів, без додаткових ремарок-вказівок. Індивідуальність, яка збурить емоційний світ глядача, викличе співпереживання. Коли ж говорити про гумористичні передачі, то тут експлуатується саме творча акторська типажність. Скажімо, знаний український письменник-гуморист Павло Прокопович Глазовий, який тісно співпрацював 3 редакторами Українського радіо, створюючи усмішки, гуморески, інтермедії для розважальних передач, часто сам редагував свої твори, враховуючи типаж того чи іншого актора, який мав виконувати його твір. До таких же прийомів вдавались автори Степан Олійник, Петро Ребро, Василь Юхимович.

Сучасні ритми життя диктують моду залучати глядача у «креативне» поле. В театрі актор останніх десятиліть перестав бути людиною в земних запропонованих обставинах. Дедалі частіше це лише «упаковка тіла». Телебачення цьому сприяє. Радіо намагається опиратися. В програмах художнього мовлення фундаментом творчого процесу залишається ідея, як головна думка твору. На телебаченні «обгортка» давно витіснила суть, про що свідчить засилля різноманітних шоу. Радіо, спираючись лише на слухоряд, утримує слухача довершеністю художнього слова. Поки що це ще вдається, але тенденції останнього десятиліття невтішні.

Розважальні передачі на радіо завжди мали глибинне наповнення. Гіпертрофований ігровий стиль життя в сьогоденні змінює ідеали духовності й краси швидше, ніж вони встигають сформуватися в людині. Гумор і сатира - це застереження, заклик. Змінюється наше життя, змінюється обличчя театру, змінюються тенденції і в засобах виразності. В радіоефірі однозначно. У постановочних програмах ігрового характеру це - пошуки в голосоведенні, ритмізація мови, особлива увага до використання резонаторів, осучаснення класичних текстів - адаптація, відверта проєкція на сьогодення, інтонація і манера спілкування, наближені до побутових. Сьогодні в гумористичних передачах переважають теми: свобода, політика, сім'я та держава, особистість і суспільство, звичайна пересічна людина, які переплітаються в тугий вузол залежностей.

«Ну що б, здавалося слова...» - загальновідомий вислів Т. Г. Шевченка.
...Швейцарський лінгвіст IX ст.. Ф. де Соссюр стверджував, що значення слів перебуває не у взаємозв'язку між річчю та ï̈ назвою, а в тонкішому поєднанні поняття та його звукового втілення в акустичному образі. Пов'язує поняття і його звукове відображення слухач - i звідси випливає, яке значення він надає почутому. (Кужельний, 2018, с. 426).

У короткій гумористичній формі, яка переважає в розважальних передачах, кожне слово дорогоцінне, значуще. А це складно, оскільки прикмета часу — суміш стилів і жанрів.

Акторська професія має багато складових, одна з них технічна, яка допомагає вправлятися в інтерпретаціях текстових форм. В ансамблевій роботі в розважальних передачах має відчуватися напрацьована дикційна вправність, легкість, широкий діапазон голосових можливостей, тембрального забарвлення. Актор повинен володіти вмінням імпровізувати і водночас бути сконцентрованим на партнерах. Особливість спілкування в радіоефірі - це діалог з партнером, який тут, у студії, поряд, і зі слухацькою аудиторією, яку не бачиш, її потрібно уявляти, дуже «реально» в своій уяві бачити і чути: як вона реагує на дотепи, як сміється. Від цього залежатиме дієвість словесна. Актор, який записує, виконує, грає інтермедії, має бути пов'язаний зі слухачем, якого не бачить, начебто мотузками, відчувати реакцію, яка має народитись у слухача, має «занурювати» у вир подій усмішок, анекдотів i, як феноменальний кулінар, «приправляти» все мовлене потрібними дозами прянощів. Часто шанувальники на творчих зустрічах розповідають, що під час звучання передачі, вони вступали в діалог, відповідали на запитання, у них народжувались якісь репліки... Це найцінніше. Мета досягнута. Творчій групі вдалося створити дійство і задіяти слухачів, впливати на них, викликати в них відповідні емоції, враження, думки. $\mathcal{C}$ й небезпека - впасти в перебільшення, а перебільшення, награвання, кривляння вбивають сміх.

У житті спілкування між людьми відбувається невимушено, природно. Щоб грати на театральному кону, доводиться вчитися театральним законам. Щоб працювати в радіоефірі актором у розважальних передачах, треба навчитися відчувати нюанси зовнішньої та внутрішньої техніки, зважаючи на жанр (гумор, сатира), на відсутність пластичних, мізансценічних процесів, на взаємодію 3 уявною аудиторією. Обов'язкова умова володіння всіма голосовими регістрами (верхній, середній, нижній), вміння легко переходити 
3 одного в інший, без напруги, вільно, непомітно для слухача. «Практика засвідчує, що інтонаційно вбога мова найчастіше народжена відсутністю у актора не лише виразних голосових даних, а й яскравого бачення, багатої творчої фантазії, справжньої словесної дії», — зазначає заслужена артистка України Зоя Віхарева — доцент кафедри сценічної мови Київського національного університету театру, кіно і телебачення ім. І. К. Карпенка-Карого. (Віхарева, 2005, с. 4) Повнозвучний голос, широта діапазону, регістри, голосова гнучкість, легкість, рухливість дають можливість збагачувати звукову палітру, а бездоганна дикція і чітка артикуляція допоможуть фахово, професійно працювати 3 мікрофоном, спрямовувати свою творчу уяву, увагу і хист на створення художніх образів. Актор наділяє героїв своїм голосом, через який «оживляє» їх. Через голос, інтонаційний малюнок ролі, підтексти, власний життєвий досвід, який проєктується на героя, робить його зримим. I, мабуть, найголовніше - в розважальних передачах можуть працювати актори, які мають почуття гумору, вміють бачити в трагічному смішне i трагічне в смішному, відчувають міру, щоб гумор не перетворився на брутальність, несмак. Цьому навчити неможливо. Цю науку осягає кожен самостійно.

Висновки. Універсальна мова театру значно розширює професійне поле акторської діяльності. Радіомистецтво - особливий вимір акторського існування. За повної відсутності зовнішніх виражальних засобів драматичний актор, завдяки прийомам внутрішньої техніки та голосу, може створювати образи героїв, які «оживають» в уяві слухача. Розважально-епатажна складова гумористичних постановочних передач ігрового характеру за відсутності репетиційного процесу, потреба імпровізувати в стилі стенд-апу вимагають від сучасного актора вміння вибудовувати безбар'єрний зв'язок зі слухачем, якого не бачить, творити емоційне поле в своїй свідомості й уяві та передавати слухачеві. Це надскладний, але можливий рівень майстерності актора.

Гумор і сатира як такі творились багатьма людьми впродовж багатьох віків. Безліч усмішок, гуморесок, анекдотів, жартів, афоризмів, приказок, гострих і дотепних висловів як безіменних авторів, так і людей зі світовими іменами, були озвучені акторами в розважальних передачах. Найпопулярнішими були рубрики «Народ скаже як зав'яже», «Таланти й шанувальники», «Без жартів», «Ох, ці жінки», «Сімейна проза», «Серйозно про сміх», «Усмішки поважних», «Що то за субота без новеньких анекдотів», «Одним рядком». Самобутньо, яскраво, а часом і неповторно грали своїх героїв талановиті актори.

Передачі «Від суботи до суботи», «А ми до вас в ранковий час» виявились довгожительками. Перша звучала на хвилях Українського радіо впродовж сорока п'яти років, друга - сорока. В житті все змінюється, немає нічого вічного. В 2017 році відбулась реформа ЗМІ, реорганізація - зникли державне телебачення і радіо. Натомість з'явилося суспільне мовлення - ПАТ Національна телерадіокомпанія. 3'явились і нові концептуальні вимоги мовлення, формати. Більшість передач було «згорнуто» як проєкти. Вищезгадані програми залишились в історії художнього мовлення, українського радіомистецтва, а з ними й імена непересічних творців, які впродовж десятиліть дарували радіослухачам веселий сміх і хороший настрій.

\section{Бібліографія}

Недін, Л. Сфери продюсування та продюсерські моделі у сучасному драматичному процесі. Радіомистецтво. 3б. наукових праць "Діяльність продюсера в культурно-мистецькому просторі ХХІ століття: творчі діалоги». Київ: НАКККіМ, 2020. С. 121-129. 486 с.

Митницький, Е. Ми живемо, доки любимо. Київ: Максимум, 1998. С. 27.

Кужельний, О. Самосвітне Сузір'я. Театральна хроновізія. Київ: САМІТ-КНИГА, 2018. С. 426.

Віхарева, 3. Робота над віршем та логічний аналіз тексту. Київ, 2005. С. 4.

\section{References}

Nedin, L. (2020). Sfery prodiusuvannia ta prodiusrski modeli u suchasnomu dramatychnomu protsesi. [Spheres of producing and producer models in contemporary drama process]. Radiomystetstvo. Zb. naukovykh prats «Diialnist prodiusera $v$ kulturno-mystetskomu prostori 21 stolittia: tvorchi dialohy». Kyiv: NAKKKiM. Pp. 121-129. [in Ukrainian]

Mytnytskyi, E. (1998). My zhyvemo, doky liubymo. [We live till we love]. Kyiv: Maksymum. C. 27. [in Ukrainian]

Kuzhelnyi, O. (2018). Samosvitne Suziria. Teatralna khronoviziia. [Theatrical chronovision]. Kyiv : Samit-Knyha. C. 426. 496 c. [in Ukrainian]

Vikhareva, Z. (2005). Robota nad virshem ta lohichnyi analiz tekstu. [Work on the verse and logical analysis of texts]. Kyiv. P. 4. [in Ukrainian] 


\section{Larysa Nedin}

\section{Features of internal and external acting technique in comedy shows of stage-feature character. Radio art}

The article examines the little-studied range of internal and external acting techniques in the related field of activity of a dramatic actor - radio art. Attention is focused on entertainment programs of staging and feature nature, participation in which significantly expands the professional range and creative palette of the actor. Emphasis on the features of internal and external technology as a means of expression in radio programs of the comedy genre.

Keywords: internal technique, external technique, radio, actor, director, rhythm, reincarnation, «From Saturday to Saturday», «We come to you in the morning».

\section{Недин Лариса Николаевна \\ Особенности внутренней и внешней актёрской техники в юмористических передачах постановочно-игрового характера. Радиоискусство}

Аннотация. В статье рассмотрен спектр внутренней и внешней актерской техники в паралельной сфере деятельности драматического актера - радиоискустве, который с научной точки зрения не исследован. Внимание сосредоточено на развлекательных передачах постановочно-игрового характера, участие в которых значительно расширяет профессиональный диапазон и творческую палитру актера. Акцент поставлен на особенностях внутренней и внешней техники - как средствах выразительности в радиопередачах юмористического жанра.

Ключевые слова: внутренняя техника, внешняя техника, радио, актер, режиссер, ритм, перевоплощение, «Від субботи до субботи», «А ми до вас в ранковий час». 